10. Galimov, A.V. (2004) Theoretical and methodological principles of preparation of future officers-border guards for educational work with personnel. Khmelnitsky: NAUDSPU. 376 p.

11. Novikov, A.M. (2010). Methodology of scientific research. Moscow: Librokom. 280 p.

12. Ivanova, S.V. (2010). Criteria and indicators of development of professional competence of Biology teachers in institutions of postgraduate pedagogical education. Scientific Journal of Ivan Franko Zhytomyr university. Pedagogical Science. 52. 152-156.

13. Grechko, S.M. (1998). Psychological and pedagogical bases of education and humanitarian training of servicemen: Educational and methodical manual for parts and units of the border troops of Ukraine. Khmelnitsky 150 p.
14. Monakhova, M. (2001.) Pedagogical design - a modern tool for didactic research. School technology. 5. 5-7.

15. Great explanatory dictionary of the modern Ukrainian language (from the supplementary). In V.T. Busel (Ed.). Kyiv; Irpen: Perun. 2005. 1728 p

16. Goncharenko, T.L. (2012). Criteria, indicators and levels of readiness of teachers in Physics to design the educational process. Bulletin of the Altai State Pedagogical Academy. 13. 33-40.

17. Bolsoviak, N. (2004). Informational competence of a specialist. Pedagogy and psychology of professional education. 5. 21-28.

\title{
ANDRIUSHCHENKO Iana,
}

Assistant of Production Management and Innovative Activity of Enterprises Department, Mykolayiv National Agrarian University

e-mail: andriushchenko@outlook.com

ESSENSE, STRUCTURE, CRITERIA, INDICATORS AND LEVELS OF READINESS OF HIGHER EDUCATION APPLICANTS IN PHILOLOGICAL SPECIALTIES FOR THE PROFESSIONAL ACTIVITY IN TERMS OF A COMPETENCE-ORIENTED COMPUTER ENVIRONMENT

Abstract. Reforming the system of higher education implies the availability of an appropriate level of professional competence for higher education applicants. Taking into account the new requirements for the training of higher education applicants, in particular future philologists, the problem of determining the readiness of future philologists for professional activity, formation and development of general and professional competencies, diagnostics of the level of acquired competencies of higher education applicants in philological specialties in terms of a competence-oriented computer environment becomes very relevant. In this regard, it is important to analyze how the future of philologists should prepare for the future, what knowledge, skills and competences should be acquired by applicants in philological specialties in order to ensure the appropriate quality of future professional activities and a high level of orientation in the reforming process of the higher education system.

The purpose of the article is to analyze the essence, structure, definition of criteria, indicators and levels of readiness of higher education applicants in philological specialties for professional activity in terms of a competence-oriented computer environment.
Thus, we can identify the main criteria and their indicators for assessing the level of readiness of higher education applicants in philological specialties for professional activity in a competence-oriented computer environment: motivational, theoretical, practical, reflexive The analysis and research of criteria and indicators of readiness of higher education applicants in philological specialties for professional activity in terms of a competence-oriented computer environment allows to determine the levels of formation of the specified readiness: elementary, medium, sufficient and high and describe their content and essence.

Keywords: higher education applicants in philological specialties; a competence-oriented computer environment; criteria; indicators; levels of readiness.

Одержано редакиією 24.08.2018 Прийнято до публікаиї̈ 29.08.2018

DOI 10.31651/2524-2660-2018-17-9-19

ORCID 0000-0001-6263-4744

\section{ВІНТЮК Юрій Вомодимирович,}

кандидат психологічних наук, доцент кафедри теоретичної та практичної психології,

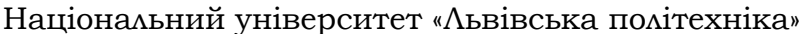
e-mail: yurvin@ukr.net

УДК 378.091.212: 159.922

\section{ДОСАІДЖЕННЯ СВІДОМОСТІ У НАВЧАМЬНІЙ РОБОТІ ЗІ СТУДЕНТАМИ-ПСИХОАОГАМИ}

У статті зроблено спробу висвітлити особливості та хід застосування досліднииького підходу до вивчення свідомості у навчальній роботі зі студентами-психологами в проиесі навчання у ВНЗ. Здійснений огляд наукових публікаиій за обраною темою; з'ясовано проблематику і підходи до дослідження свідомості. Висвітлено особливості дослідження свідомості у психології в різні періоди ї̈ становлення. Розглянуто специфіку залучення студентів до дослідження свідомості, на кожному з етапів ї вивчення. Зроблені висновки з проведеної роботи і намічено перспективи подальших досліджень $у$ даному напрямку.

Ключові слова: дослідження свідомості; досліднииький підхід у навчальному проиесі; 
психологічний роман; психологічний аналіз; інтроспекиія; потік свідомості; навчальна робота зі студентами-психологами.

Постановка пробцеми. Підготовка фахівців 3 вищою освітою у сучасних умовах вимагає застосування відповідних підходів, які дозволяють простежити хід розвитку науки, процес здобуття знань у межах різних течій, напрямків i шкіл, що необхідно для формування уявмень про її сучасний стан. Дана обставина повністю стосується і підготовки майбутніх фахових психологів: студенти повинні здобути адекватні уявлення про базові поняття психологічної науки, що важливо для їхнього подальшого успішного професійного становлення. До таких понять, які потребують ретельного опрацювання, починаючи з першого курсу навчання, належить і поняття свідомості, причому Аише теоретичних знань не достатньо для його повноцінного розуміння. Дана обставина зумовлює необхідність впровадження дослідницького підходу в навчальний процес, який передбачає застосування елементів дослідження на різних його етапах; що підтверджує актуальність даної роботи.

Проблема, що перебуває у центрі розгляду в даній роботі, полягає у тому, що студентам першого курсу, які знайомАяться з явищем і проявами свідомості у межах курсу "Загальна психологія", важко освоїти як сутність даного психологічного феномену, зрозуміти сучасні підходи до пояснення іiі функціонування, осягнути накопичені знання та методи досмідження, за допомогою яких вони були здобуті; а тому наявне протиріччя у підготовці майбутніх психологів, що потребує застосування відповідного підходу, який би допоміг у його вирішенні.

Мета роботи: висвітлити особливості та хід застосування дослідницького підходу до вивчення свідомості у навчацьній роботі зі студентами-психологами.

\section{Завдання дослідження:}

- здійснити огляд наукових публікацій за обраною темою; з'ясувати тематику і підходи до дослідження свідомості;

- висвітлити особливості дослідження свідомості в різні періоди;

- розглянути специфіку залучення студентів до дослідження свідомості, на кожному з етапів ії вивчення;
- зробити висновки 3 проведеної роботи і намітити перспективи подальших досліджень у даному напрямку.

Дана робота виконана в контексті попередніх досліджень, 3 формування професійної компетентності майбутніх фахових психологів, і $є$ їнім подальшим продовженням (див., напр.: [1; 2] та ін.).

Анаціз останніх досліджень $і$ пубмікацій. Сучасні науковці нерідко звертаються до вивчення свідомості, різних аспектів, хоча ці дослідження не належать до пріоритетних. Відповідно, наукових публікацій з актуальних проблем їі дослідження, як вітчизняних, так і зарубіжних вчених, виявлено небагато. Передусім необхідно згадати праці попередників, які до сьогодні не втратили свого значення, оскільки містять важливі методологічні підходи до вирішення проблеми свідомості. Це публікації

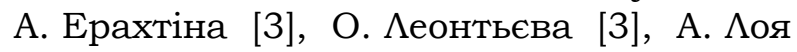

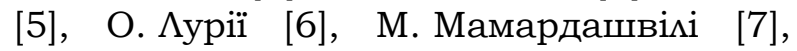
Ф. Михайлова [8], О. Спіркіна [9] та ін.

Варто також відзначити і подальші дослідження, як вітчизняних, так і закордонних вчених: С. Авраменко [10], А. Агафонова [11], С. Грофа [12], М. Джеффрі [13], Е. Ноймана [14], Х. Пантема [15], Г.Т. Ханта [16] та ін. 3 найновіших публікацій варто назвати науковців, які займаються розробкою психосемантичної теорії свідомості: О. Артем’єву, В. Петренка, В. Сєркіна, Ю. Тимош, О. Шмельова (цит. за [17]) та ін.

У працях науковців, які займалися дослідженням феномену свідомості, розглянуто широке коло питань, пов'язаних як зі з'ясуванням іï походження, сутності, особливостей функціонування, так i практичного застосування цих знань. Здійснений огляд мітературних джерел не наводиться, оскільки цього не дозволяє зробити обмежений обсяг публікації, проте окремі необхідні положення наведені в ході викладу матеріалу власного дослідження.

Незважаючи на те, що основні положення щодо сутності, походження, особмивостей дослідження та функціонування свідомості у наявній науковій $і$ тературі 3 даної тематики висвітлені достатньо повно, інформації про те, як саме доцільно, на раціональних засадах, ознайомлювати 3 цими знаннями студентів- 
психологів, ані викладу досвіду подібної роботи, практично немає. Оскільки окремі розрізнені дані не дають цілісної картини явища, що вивчається, дана обставина вимагає застосування відповідного підходу, який би дозволив освої-

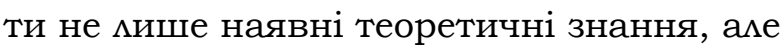
й практичні навички дослідження свідомості, а також вказав можливості застосування цих знань. Дана обставина змушує до висвітлення цього аспекту проблеми у самостійному дослідженні.

Викцад основного матеріалу. Проведене дослідження полягало у здійсненні спроби виробити та реалізувати певний оптимальний підхід до ознайоммення студентів із дослідженням свідомості, який би дозволив поєднати наявні розрізнені знання про предмет викладу на певній раціональній основі, подати їх доступно й у строгій могічній послідовності, виходячи 3 їхніх потреб у таких знаннях, наявного рівня знань і вимог професійної підготовки. Дия створення такого підходу спеціальне дослідження не проводимося, використано наявний досвід викладання, відповідно, його формування не можна вважати завершеним. При реалізації підходу ставилося завдання максимально наблизити наукові теорії до повсякденного життя кожної Аюдини, щоб зробити їх зрозумілими для студентів. На кожному етапі дослідження містить як аналітичну, так і практичну складову; організовується та проводиться викладачем, проте з максимально можливим залученням студентів; здійснюється як в аудиторній, так і позааудиторній навчальній діяльності. Вироблена доцільна послідовність проведення дослідження, як викладу матеріалу, так і його практична компонента, в скороченому вигляді, наведена далі.

1. Передісторія дослідження свідомоcmi. Виклад теми розпочинається з ознайомлення студентів із початком накопичення знань про свідомість мюдини. Відзначається, що даною проблемою дослідники цікавилися у різні часи, починаючи з Античності, проте тоді, як і пізніше, іх цікавили передусім розмади свідомості що визначало можливість мюдини бути повноцінним чценом суспільства, іiі спроможність до продуктивної діяльності; а також змінені стани свідомості, у зв'язку з містичними і релігійними практиками. Крім цілителів і служителів культів займалися вивченням свідомості також філософи, але іх цікавили передусім суто філософські аспекти пов'язаної 3 нею проблематики; у той час як віщуни, маги, шамани займалися практичними питаннями впливу на психіку, що походими з досвіду. Така ситуація зберігалася аж до фімософсько-теоретичного обгрунтування проблеми свідомості, що було зроблено у працях Декарта_i $\Lambda$ окка в XVI-му столітті (про що студентам відомо 3 попередніх тем). Проте як суто філософсько-аналітичні, так i містичнопрактичні способи дослідження свідомості мало придатні дмя підготовки практичних психологів на сучасному рівні.

2. Початок наукового дослідження свідомості. Від початку виникнення першого напрямку наукової психології, структуралізму В. Вундта, предметом дослідження була свідомість, а методом дослідження - інтроспекція. Він хотів побудувати психологію як природничонаукову дисципліну; відповідно, вчений визначає її як науку про властивості свідомості, елементи свідомості та зв'язки між ними. Тут виникає необхідність пояснити студентам, як саме здійснювалися дослідження свідомості методом інтроспекції, а також основні положення струкруралізму, побудовані на них. Розуміння даного методу як з позицій досягнень того часу, так і сучасні тлумачення наявні у спеціальній мітературі (див., напр. [18; 19] та ін.); дані положення наводяться, пояснюються і обговорюються. За необхідності окремі питання даються студентам для самостійного опрацювання.

Виходячи зі своїх досліджень, Вундт видімив першу властивість свідомості організованість, структурованість. Вона $\epsilon$ структурою організованих елементів; ці елементи бувають об'єктивні та суб'єктивні. У термінології Вундта одиничним об'єктивним елементом свідомості є просте враження; це значить що воно не розкладається на дрібніші одиниці. Неподільним елементом свідомості є відчуття; наприклад, відчуття - це просте враження, яке виникає, коли ми чуємо окремий удар метронома. А якщо два удари або більше, то це вже уявлення; 
відповідно, відчуття і уявлення є об'єктивними елементами свідомості. Суб'єктивні елементи свідомості - це елементи, пов'язані з самим суб'єктом, тобто внутрішні, що йдуть від нього самого; такими елементами свідомості є почуття (емоції). Згідно з Вундтом, свідомість організована; елементи у полі свідомості утворюють зв'язку, вони структуровані. Таким чином, поле свідомості становить структуpy, і в центрі цієї структури є центральна точка - це те, на що ми звертаємо увагу. Цю точку, фокус уваги теж оточує певна область; можна сказати, що навколо цієї точки $€$ центральна частина поля свідомості, яке називається полем уваги [20].

На цьому етапі розкриття проблеми студенти все ще не наважуються ні висловити своє ставлення до отриманих знань, ні тим більше повторити деякі 3 експериметальних досліджень В. Вундта і його послідовників - що було їм запропоновано - тобто не включаються у процес дослідження. Звідси слідує, що освоєння навіть перших етапів експериментальних досліджень свідомості не буде простим. З'ясоавно, що до труднощів, які в даному випадку зустрічають студенти, слід віднести передусім відсутність досвіду спостереження за своїм внутрішнім світом - вмістом вцасної свідомості, - а також несформованість уявлень про зв'язок вмісту свідомості з дійсністю та можАивостями практичного застосування цих знань. Тут потрібно повернутися щонайменше на століття назад, і розповісти про те, яким чином починалося освоєння вмісту свідомості, на прикладі художньої мітератури, оскільки 3 нею студенти не погано ознайомлені.

3. Дослідження свідомості в літераmypi. В XVIII ст. у художній цітературі виникає предтеча психологічного роману - сентиментальний роман, основоположником якого став англійський письменник $\Lambda$. Стерн. Письменникисентименталісти надавали перевагу мюдським почуттям, у центрі їхньої уваги було зображення внутрішнього світу своїх героїв. Тож для ілюстрації вмісту сві-

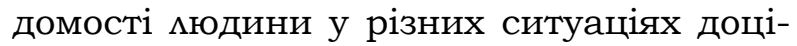
Аьно скористатися фрагментами з їнніх творів. Саме Стерн найбільше причетний до відкриття і висвітлення глибин внутрішнього світу Аюдини, які згодом отри- мали продовження у психологічному романі.

Далі доцільно перейти до розгляду еволюції цієї цітературної традиції, починаючи від першої половини XIX ст., коли виникає психологічний роман, як самостійний жанр. Його основоположником вважається французький письменник Стендаль; у другій половині століття найкращі психологічні романи створили російські письменники $\Lambda$. Толстой i Ф. Достоєвський (причому з творами цих авторів студенти знайомі). Ними було зроблено важливе відкриття, що мало вплив на подальший розвиток не мише світової мітератури: психологічний анаміз. До цього феномен мислення розумівся як простий відгук свідомості на факт дійсності, тобто думка повністю відповідала фракту і була рівною йому. Толстой

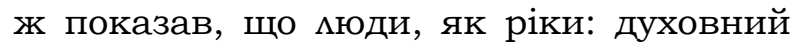
світ текучий, думка тільки відштовхується від факту, в акті мислення бере участь весь попередній досвід Аюдини, і думка поєднує сьогодення, минуле та майбутнє; думка бере участь у переробці факту в світАі всього життєвого досвіду мюдини; в акті мислення задіяні не тільки аналітична та синтетична здатності мозку, але i пам'ять, і уява і фантазія. Аналітичне усвідомлення, опис факту, що йде в минуле, виявляється "симетричним" по відношенню до майбутнього, до прорікання і передбачення [21]. Отже, констатуємо, що психологічний роман - це різновид роману, у якому автор ставить за мету зображення та дослідження "внутрішніх станів Аюдини" i "найтонших порухів іï душі", тобто вмісту їі свідомості. Як приклади його відтворення у психологічному романі доцільно використати фрагменти 3 творів представників цього жанру; іх необхідно обговорити і проаналізувати 3 максимальним залученням студентів.

Подальшу еволюцію як жанру психомогічного роману, так і дослідження внутрішнього світу мюдини, продовжує модерний психологічний роман XX ст. Однак його появі передували важливі події в науковому світі, пов'язані з розвитком наукової психології на межі XIX - XX стоміть. Нове явище в мітературі, що поширювалося й еволюціонувало понад століття, не залишилося поза увагою психологів. Науковці неодмінно повинні були зацікавитися ним, хоча б через те, що 
письменники художніми засобами намагалися вирішувати ті ж завдання, які стояли на той час і перед психологами з'ясування вмісту свідомості та пояснен-

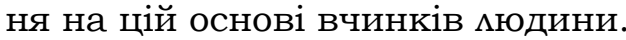

4. Потік свідомості в психології. Найважливіша подальша віха у цій низці подій, яка мала значний вплив на подаиьше вивчення свідомості й, відповідно, становлення психології а також художньої мітератури: американський психолог У. Джеймс ввів термін "потік свідомості", у праці "Основи психології" (1890). Він вважав, що свідомість мюдини подібна до потоку, річки, в якій думки, відчуття, асоціації перебивають одне одного і немогічно переплітаються; відомо, що вперше потік свідомості застосував у иітературному творі французький прозаїк Е. Дюжардан, у романі "Повержені маври" (1888); (значно раніше таку спробу здійснив $\Lambda$. Толстой, в оповіданні «Історія вчорашнього дня", 1851). Запропонований Джеймсом термін об'єднав різні типи внутрішнього монологу (Аітературний опис внутрішніх процесів мислення, техніка зображення думок і почуттів, що проходять через свідомість, зображення духовних процесів) [21]. Значний інтерес з огляду розкриття теми і виконання поставлених завдань становить розгляд основних положень щодо поняття "потік свідомості» та їхній аналіз. Цю роботу доцільно розпочати з праці У. Джеймса [22], (проте згодом варто ознайомитися також з сучасними поглядами на предмет розгляду, напр.: [23]); спочатку відзначається, що йдеться про іншу точку зору на ту ж саму проблему, оскільки автор критикує позиції структуралізму В. Вундта і Е. Тітчнера.

Свої міркування У. Джеймс розпочинає 3 констатації наступного: Первинним конкретним фактом, який належкить до внутрішнього досвіду, є переконання, що в цьому досвіді відбуваються якісь свідомі процеси. Стани свідомості змінюються в ньому один одним. Подібно до того, як ми висловлюємося безособово: "світає", "сутеніє", ми можемо і цей факт охарактеризувати найкраще безособовим дієсловом "думається". Вчений розмірковує над тим, як здійснюються свідомі процеси, і відзначає, що в них помітні чотири суттєві риси: 1) кожен стан сві- домості прагне бути частиною особистої свідомості; 2) у межах особистої свідомості її стани мінливі; 3) будь-яка особиста свідомість становить неперервну послідовність відчуттів; 4) одні об'єкти вона сприймає охоче, інші відкидає i, взагалі, постійно робить між ними вибір [22]. Дані положення виносяться на обговорення, за потреби наводяться фрагменти їхнього подальшого розгляду в праці У. Джеймса. Студентам ставиться завдання з'ясувати сутність даного явища і сформулювати його визначення.

В результаті спільного обговорення констатується, що потік свідомості - ие неперервний ряд психічних відображень (думок, образів, спогадів, відчуттв та уявлень тошо) які представлені у психіиі людини, доступні самоспостереженню $i$ становлять ї̈ внутрішню психічну реальність. Далі завдання поступово ускладнюються, пропонується з'ясувати: що фіксує свідомість у кожен момент часу? Які закони цього відображення? Виявляється, вона не фіксує нічого несуттєвого, постійно ведеться пошук і відбір найважливішої, життєво значущої інформації, придатної для використання; причому інформація поступає одночасно по багатьом каналам, а свідомість постійно сканує іiі, відшукуючи потрібну, актуальну в даний момент. Проте з'ясувати походження і призначення ряду елементів свідомості не вдається; прослідкувати іхню послідовність і зв'язок між ними виявляється ще важче. Цей етап обговорення завершується формулюванням визначення: неперервний проиес відображення свідомістю явищ дійсності - y всьому їх багатоманітті - називається потоком свідомості.

Далі Джеймс розмірковує наступним чином: "У свідомості відбуваються постійні зміни. Цим я не хочу сказати, що ні один стан свідомості не має протяжності; навіть якби це було правдою, то довести

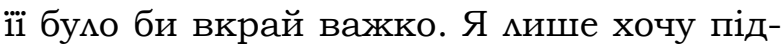
креслити той факт, що ні один стан свідомості, що минув, не зможе знову виникнути і повторитися буквально. Ми то слухаємо, то розмірковуємо, то пригадуємо, то очікуємо, то мюбимо, то ненавидимо, наш розум позмінно зайнятий тисячами різних об'єктів думки" [22]. У результаті розгляду причин такої мінливос- 
ті вмісту свідомості автор відзначає: "Мені видається, що аналіз цілісних, конкретних станів свідомості, які змінюють одні одних, є єдино вірним психологічним методом, як би не було складно строго провести його через всі нюанси дослідження. Якщо спочатку він і видається читачу темним, то при подальшому викладі його значення проясниться". Дана думка якнайкраще відображає і сутність запропонованого та використаного підходу; розмірковуючи над нею, студенти з цим також погоджуються. Тут необхідно відзначити, що невдовзі і положення У. Джеймса також зазнають критики з боку представників інших психологічних напрямків, які теж заслуговують ретельного розгляду й аналізу. Тобто завдання ускладнюється: потрібно не тільки шукати підтвердження положенням, які доводить автор, але й готувати контраргументи.

Проте повертаємося до праці Джеймса, який далі звертає увагу на те, що в потоці свідомості різні його частини мають різну швидкість плину. "Пункти зупинок у свідомості звичайно бувають зайняті чуттєвими враженнями, особливість яких полягає в тому, що вони можуть, не змінюючись, споглядатися розумом невизначений час; перехідні проміжки зайняті думками про відношення статичних і динамічних, які переважно встановцюються між об'єктами, сприйнятими у стані відносного спокою" [22]. Тобто в свідомості періодично відбувається то одержання інформації від органів відчуттів, то ії обробка мозком. Цей факт видається очевидним, хоча до цього ніхто з учасників дослідження не висловив подібної думки про закономірності роботи свідомості. Джеймс приходить до думки, що наше мислення постійно прагне від однієї стійкої частини, щойно покинутої, до іншої; можна сказати, що головне призначення перехідних частин свідомості в тому, щоб спрямовувати нас від одного міцного, стійкого висновку до іншого.

Після необхідних роз'яснень студентам пропонується назвати всі складові і зобразити схематично структуру потоку свідомості. (Детальний розгляд цього питання, як і аналіз наведених відповідей заслуговують окремого висвітлення). Схема, що складається з названих ком- понентів, одночасно малюється на дошці. Далі, з допомогою наявних знань, розглянутих прикладів із художньої мітератури та розробленої схеми студентам пропонується зафіксувати і відтворити (записати) вцасний потік свідомості, в даний момент i за певний обмежений період часу. Маючи належну попередню підготовку, вони включаються в процес дослідження. Після перевірки їхніх робіт найкращі з них оприлюднюються і обговорюються; а також з'ясовуються причини, що перешкодими іншим студентам справитися з цим завданням. У будьякому випадку, наявний бар'єр, що заважав навіть найактивнішим і достатньо добре підготованим студентам включитися в процес запропонованого дослідження, подолано. Проте дослідження продовжується, і поступово до нього домучаються й інші учасники.

5. Розуміюча психологія $i$ вивчення свідомості. За подальшою могікою викладу слід нагадати про те, що наприкінці XIX ст. виник напрямок психологічних досліджень, який мав за мету осяг-

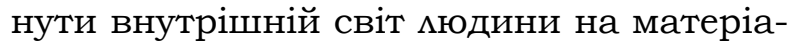
$\Lambda і$ художніх творів. Його започаткував німецький філософ В. Дільтей, який вважав, що психологія, яка базується на пояснюючих методах, запозичених із природничих наук, - не може дати цілісного розуміння мюдини як реальної, живої особистості. Ї̈̈ місце повинна зайняти розуміюча психологія, згідно з якою головним завданням психологічного дослідження є не причинне пояснення душевного життя людини, а розуміння шляхом співвіднесення його внутрішніх змістових утворів (переживань) зі світом культурно-історичних иінностей. Дікьтей стверджував: "природу ми пояснюємо, а душевне життя розуміємо". В основі цієї ідеї межало протиставлення наук про природу наукам про суспільство i заперечення самої можливості вивчити соціально-історичну обумовленість психіки мюдини за допомогою об'єктивних, у тому числі експериментальних, наукових методів [23, с. 127].

Дільтей приймає поді^ і протиставмення наук про природу та про дух. Природознавству доступний мише досвід,

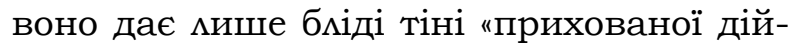
сності", а науки про дух спрямовані на внутрішній досвід, мають предметом 
самосвідомість. Природничі науки здійснюють пізнання того, що доступно органам відчуттів - зору, слуху, смаку та ін., спостерігають розрізнені факти і встановАюють зв'язки між ними, а науки про дух мають справу з прихованою, недоступною зовнішнім органам відчуття реальністю, яка пізнається за допомогою переживання, інтуїтивно схопленою тотальністю (цілісністю) життя. Дільтей протиставляє пояснення, здійснюване 3 допомогою розуму в науках про природу на основі каузальності, аналізу, систематизації, могічного виведення й т. д., і розуміння, що реалізується в науках про дух, інтуїтивне проникнення одного життя в інше. Метод розуміння становить зі себе безпосереднє осягнення деякої духовної цілісності; на думку вченого, природу ми пояснюємо, а душевне життя розуміємо.

Дільтей розрізняє природничонаукову i духовно-наукову психологію. Перша виділяє у свідомості ізольовані, однозначні, певні емементи ("атоми"), застосовує метод пояснення; це - пояснювальна психологія. Дільтей піддає критиці таку психологію за поширення природничо-наукових понять на область духовного життя, стверджує, що їі гіпотези про "атоми" бездоказові. Духовнонаукова психоцогія є "описовою", осмис-

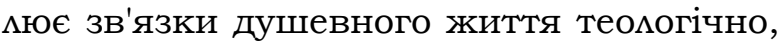
представцяє внутрішні переживання психічної сфери як пов'язані цілісності, як смислові утворення, включені в історію культури. У цій психології головним $\epsilon$ не причинне пояснення душевного життя, а його розуміння шляхом співвіднесення внутрішніх смислових утворень (переживань) зі світом культурноісторичних цінностей. Дільтей вважав, що розуміння власного внутрішнього світу здійснюється за допомогою інтроспекції (самоспостереження), а духовного світу іншого - 3 допомогою "співпереживання", "вживання", "співвідчуття". Він прийшов до висновку, що внутрішній досвід, при якому відбувається самозаглиблення у вцасні стани, не дає можливість усвідомити власну індивідуальність: тільки у порівнянні себе з іншими Аюдина усвідомлює свою індивідуальність [23, с. 356]. Необхідний дмя цього матеріал був наявний у художніх творах, головним чином, у психологічних романах.

Розуміння, будучи зверненим до куцьтури минулого, здійснює інтерпретацію, тлумачить окремі явища як елементи духовного життя відтворюваної епохи; таке розуміння-інтерпретацію Дільтей назвав герменевтикою (від грец. пояснюю, тиумачу). Розуміння передбачає проникнення у духовний світ автора тексту, що включає реконструкцію культурного контексту, в якому створювався текст. Це розуміння вводить суб'єктивні переживання у смислові зв'язки, які існують поза суб'єктом духовної культури в мистецтві, релігії, моралі, праві.

Основне завдання розуміючої психомогії - розкрити змістовий сенс душевного життя Аюдини, систему іï цінностей. «Не можна не побажати появи психомогії, - писав Дільтей, - здатної вцовити у сіті своїх описань те, чого у творах поетів і письменників міститься більше, ніж у нинішніх вченнях про душу". Предметом такої психології повинен стати розвиток душевного життя у всій його повноті. Описова психологія в той же самий час повинна бути аналітичною, і в аналіз варто вкАючити живий, художній процес розуміння. Розуміюча психологія прагнума одержати і зібрати відомості про емементи свідомості, які необхідні та достатні для того, щоб уявити всю течію індивідуального душевного життя. Хорошими психологами, на думку Дільтея, є письменники, історики, актори, педагоги, мікарі [23, с. 356]. Оскільки фактично запропоновано скористатися здобутками Аітератури, а саме накопиченим фактичним матеріалом про вміст свідомості та особливості їі функціонування, дия вирішення завдань психології, наведені положення $€$ належним обгрунтуванням наведеного раніше, і слугують орієнтиром для продовження викладу.

6. Психологічний роман XX cm.: зміна парадигми. Здобутки психологічної науки у галузі дослідження свідомості на межі XIX - XX ст. мали вагомий вплив не

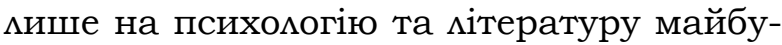
тнього, але й на подальше становлення мистецтва взагалі. 3 огляду на це потрібно розповісти про появу та розвиток модерного психологічного роману. Розвинуті в психології теоретичні положення "по- 
току свідомості" невдовзі не $и$ зне знову повернулися в мітературу, але й змінили iii, створивши мистецтво майбутнього (фактично відбулася зміна мистецької парадигми). Початок цьому процесу бумо покладено у 1915 році, коли французький письменник М. Пруст опублікував першу книгу роману «В пошуках втраченого часу", в якому використав мистецьку техніку зображення "потоку свідомості»; що ознаменувало вихід мистецтва на якісно новий рівень, через відкриття й освоєння нових можливостей. Відповідно до сучасних уявмень, у мітературі "потік свідомості" - ие художній засіб зображення внутрішнього світу людини, шо полягає у безпосередньому відтворенні "зсередини" плину ї̈ роздумів, переживань, настроїв як складного психологічного свідомо-підсвідомого проиесу, своєрідний спосіб фіксаиї та вираження найприхованіших складників иього npouecy [21].

Дамі студентам необхідно розповісти про основні здобутки мітератури ХХ ст., передусім про творчість Д. Джойса [24] та В. Вумьф [10], а також інших представників школи "потоку свідомості" в художній мітературі [25], навести фрагменти з їніх творів і здійснити їній аналіз із позицій психомогії.

Крім цього, студентам рекомендовано не $и$ ознайомитися 3 основними надбаннями психологічної художньої прози, але й регулярно читати твори психологічного спрямування, сучасні у т. ч., а також й переглядати створені за іхніми мотивами кінофільми, аналізувати ïx тощо. Дослідити сучасний стан як психологічної прози, так i модерного психологічного роману студентам пропонується самостійно.

Після здійснення аналітичного дослідження необхідно закріпити отримані знання, а також надати практичні навички 3 їхнього застосування. Внаслідок проведеної підготовки студенти починають долучатися до досліджень свідомості 3 застосуванням методу інтроспекції, одержавши необхідну кількість прикладів, вони відтворюють експерименти кінця XIX ст.

Проте на цьому досмідження свідомості у навчальному процесі зі студентами-психологами не завершується; далі їм пропонується проаналізувати як сам ме- тод, так і отримані в ході дослідження результати 3 відомими їм здобутками психомогії XX ст., а також вмасного досвіду.

7. Завершення $i$ результати дослідження. Перед завершенням дослідження доцільно поставити наступне питання: що нового можна сьогодні сказати про вміст свідомості, враховуючи здобутки сучасної психомогічної науки? Які нові особливості свідомості було відкрито? Які нові методи іiі досиідження розроблено і використано? Адже мюдина не просто спостерігає випадкову послідовність сприйняттів: вона відчуває і усвідомиює потреби, формує мотиви, діє тобто керує потоком сприйняттів. Наявна спрямованість і вибірковість потоку, мюдина одні образи сприймає, а інші створює сама. Ставиться завдання скласти алгоритм роботи свідомості, і реалізувати його у вигмяді комп'ютерної програми. На цьому дослідження доводиться припинити, оскімьки студенти дуже мало ознайомлені як зі здобутками сучасної психології, так і з мовами програмування; проте має не погані перспективи 3 огляду на можиивість продовження в майбутньому. Одержані в ході дослідження знання i досвід, до яких були залучені студенти, можуть реалізуватися згодом, на новому рівні.

Щодо результатів застосування запропонованого дослідницького підходу у навчальному процесі, варто відзначити наступне. Студентам було вперше наочно продемонстровано процес розвитку науки, здобуття i накопичення наукових знань, у межах одного, конкретного та доступного дия їхнього розуміння підході. Це дозволило показати їм психологію 3 іншого боку (не з "парадного", через підручник, а зі "службового входу" - через мабораторію дослідника); залучити їх до своєрідного "ритуалу священнодійства", що складає таїнство науки, доступне $\Lambda$ ше обраним. А ще дозволимо актуалізувати у них інтерес до наукових досліджень, вивчення методів і процедури їхнього проведення, аналізу одержаних результатів і здійснення узагальнень. Проведена робота сприяла також формуванню мотивації залучення до науково-дослідної роботи, у найпідготовценіших студентів. Вони зрозуміли, як виникають і фрормуАюються наукові проблеми, як розробця- 
ються методи їхнього дослідження тощо. А головне - звідки беруться ті знання, які поміщено у підручниках з психології, що, своєю чергою, сприяло формуванню іншого ставлення до них, як і до процесу своєї фрахової підготовки у ВНЗ.

Подібні дослідження варто продовжувати, впроваджуючи дослідницький підхід у навчальний процес, також при викладанні інших навчальних курсів. Цей шлях видається плідним, враховуючи як недосконалість і низьку результативність наявних традиційних підходів і методів викладання, так досвід проведення даного дослідження, а також здобуті результати дозволяють оптимістично оцінити подальші перспективи його продовження, впровадження та поширення.

Висновки i перспективи подапьших досліджень.

1. Огляд наукових публікацій за обраною темою дозволяє констатувати, що наявні праці містять Аише певну сукупність розрізнених даних, які важко об'єднати у цілісну концепцію, придатну дия викладання і розуміння студентами; що створює певні труднощі як у іiі викладанні, так і освоєнні студентами.

2. Застосування дослідницького підходу до висвітлення даної теми у ході іï викладання студентам-психологам дозволяє систематизувати наявні знання, викласти їх у певній могічній послідовності, зробити доступнішими і зрозумілішими, а відповідно, сформувати позитивну мотивацію до ії вивчення та подолати низку труднощів, пов'язаних з її опануванням.

3. Впровадження запропонованого підходу дозволяє підняти інтерес до вивчення даної теми у студентів, зацікавити їх до самостійного вивчення інших їі аспектів, методів і перспектив дослідження свідомості, що має позитивний вплив на залучення ix до науководослідницької діяльності, а також на процес їхнього фахового становцення в ході професійного навчання.

У майбутньому передбачено допрацювати даний підхід, до рівня науковометодичної розробки з вивчення студентами спеціальності "Психологія" даної теми $з$ подальшим впровадженням у навчальний процес; а також продовжити дослідження, 3 застосуванням даного підходу, інших тем, при вивченні подамьших навчальних дисциплін.

\section{Список бібліографічних посимань}

1. Вінтюк Ю. В. Компетентнісний підхід у підготовці майбутніх фахових психологів у ВНЗ. Молодий вчений. 2017. № 3 (43). Ч. II. С. 245-249.

2. Вінтюк Ю.В. Концепція формування професійної компетентності майбутніх психологів у ВНЗ. Молодий вчений. 2017. № 4(44). Ч. III. С. 351-355.

3. Ерахтин А.В. Диалектика становления мышления и сознания. Свердиовск, 1989. 210 с.

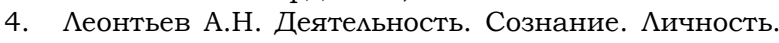
М.: Политиздат, 1977.304 с.

5. Кой А.Н. Сознание как предмет теории познания. Киев, 1988. 246 с.

6. Курия А.Р. Язык и сознание. М., 1979. 320 с.

7. Мамардашвили М.К., Пятигорский А.М. Символ и сознание. М., 1997. 224 с.

8. Михайлов Ф.Т. Общественное сознание и самосознание индивида. М., 1990. 222 с.

9. Спиркин А. Г. Сознание и самосознание. М., 1972. 303 c.

10. Авраменко С. Потік свідомості як засіб вираження внутрішнього світу персонажів (на матеріалі роману Вірджинії Вульф "Хвилі»). Вісник Аьвівського університету. Серія іноземні мови. 2014. Вип. 22. С. 241-247.

11. Агафонов А.Ю. Основы смысловой теории сознания. СПб.: Речь, 2003. 296 с.

12. Гроф С. Космічна свідомість. Київ, 2001. 268 с.

13. Джеффрі М. Коріння свідомості. Київ. 1995. 182 c.

14. Нойман Э. Происхождение и развитие сознания М.: Рефь-бук; Київ: Ваклер, 1988. 464 с.

15. Патнэм Х. Философия сознания. М., 1999. 240 с.

16. Хант Г.Т. О природе сознаия: с когнитивний, феноменологической и трансперсональной точек зрения. М.: АСТ, 2004. 555 с.

17. Тимош Ю.В. Психосемантичні дослідження свідомості особистості: [Електронний ресурс]. Режим доступу: http:/ /www.inforum.in.ua/conferences/16/25/169

18. Гиппенрейтер Ю.Б. Метод интроспекции и проблема самонаблюдения. Введение в общую психологию. М.: Изд-во МГУ, 1988. С. 34-47.

19. Поляков О.В. Феноменология психических репрезентаций. СПб.: Питер, 2011. 268 с.

20. Пєтухов О.В. Свідомість як предмет психології: [Електронний ресурс]. - Режим доступу: http://psychologis.com.ua/soznanie_kak_predmet_ psihologii.htm

21. Аітература "потоку свідомості". Духовний світ персонажів, не пов'язаний 3 реальністю: [Електронний ресурс]. - Режим доступу: http://stud.com.ua/13034/kulturologiya

22. Джеймс У. Поток сознания: [Електронний ресурс]. - Режим доступу: http://www.psychologyonline.net/articles/doc-30.html

23. Большой психологический словарь / Под ред. Б.Г. Мещерякова, В.П. Знченко. СПб.: Питер, 2002. $632 \mathrm{c}$.

24. Основні ідеї феномену "потоку свідомості" Вільяма Джеймса: [Електронний ресурс]. - Режим доступу: http://naub.oa.edu.ua/2014/osnovni-ideji

25. Метод "потоку свідомості" у творчості Дж. Джойса: [Електронний ресурс]. - Режим доступу: http://pidruchniki.com/12631113/literatura

26. Творчість Д. Джойса і школа "потоку свідомості". [Електронний ресурс]. Режим доступу: http://ukrbukva.net/3425-Tvorchestvo-DzheiymsaDzhoiysa 


\section{References}

1. Vintiuk, Yu.V. (2017). Competency approach in the training of future professional psychologists in universities. Young scientist. 3(43). 245-249. (in $\mathrm{Ukr})$.

2. Vintiuk, Yu.V. (2017). Concept of formation of professional competence of future psychologists in higher educational institutions. Young scientist. 44. 351-355. (in Ukr).

3. Erakhtyn, A.V. (1989). Dialectics of the formation of thinking and consciousness. Sverdlovsk. (in Rus).

4. Leontev, A.N. (1977). Activity. Consciousness. Personality. Moskow: Polytyzdat. (in Rus).

5. Loi, A.N. (1988). Consciousness as a matter of the theory of knowledge. Kyiv. (in Rus).

6. Luryia, A.R. (1979). Language and Consciousness. Moskow. (in Rus).

7. Mamardashvyly, M. K. \& Piatyhorskyi, A.M. (1997). Symbol and Consciousness. Moskow. (in Rus).

8. Mykhailov, F.T. (1990). The public consciousness and self-consciousness of the individual. Moskow. (in Rus).

9. Spyrkyn, A.H. (1972). Consciousness and selfawareness. Moskow. (in Rus).

10. Avramenko, S. (2014). Flow of consciousness as a means of expressing the inner world of characters (based on novel Virginia Woolf "Waves"). Visnyk of the Lviv National University named after. Ivan Franko: Series Foreign Languages. 22, 241-247 (in Ukr).

11. Ahafonov, A.Iu. (2003). Fundamentals of the semantic theory of consciousness. St. Petersburg: Rech. (in Rus).

12. Hrof, S. (2001). Cosmic consciousness. Kyiv, 2001. (in Ukr).

13. Dzheffri, M. (1995). Roots of consciousness. Kyiv. (in Ukr).

14. Noiman, Э. (1988). The origin and development of consciousness. Moskow: Refl-buk; Kyiv : Vakler. (in Rus)

15. Patnэm, Kh. (1999). Philosophy of consciousness. Moskow. (in Rus).
16. Khant, H.T. (2004). On the nature of consciousness: from the cognitive, phenomenological and transpersonal points of view. Moskow: AST. (in Rus).

17. Tymosh, Yu.V. Psychosemantic studies of personality consciousness. Retrieved from http: / / www.inforum.in.ua/conferences / 16/25/169 (in Ukr).

18. Hyppenreiter, Yu. B. (1988). Method of introspection and the problem of introspection. Introduction to general psychology. Moskow: MHU. 34-47. (in Rus).

19. Poliakov, O.V. (2011). Phenomenology of mental representations. St. Petersburg: Pyter. (in Rus).

20. Pietukhov O.V. Consciousness as an object of psychology. Retrieved from http://psychologis.com.ua/soznanie_kak_predmet_ psihologii.htm (in Ukr).

21. Literature "flow of consciousness". Spiritual world of characters, not related to reality. Literatura "potoku svidomosti". Retrieved from http:/ / stud.com.ua/13034/kulturologiya (in Ukr).

22. Dzheims, U. The flow of consciousness. Retrieved from http://www.psychologyonline.net/articles/doc-30.html (in Rus).

23. Great psychological dictionary. (2002). In B.H. Meshcheriakova, V.P. Znchenko (Ed.). - St. Petersburg: Pyter. (in Rus).

24. The main ideas of the phenomenon of "flow of consciousness" by William James. Retrieved from http://naub.oa.edu.ua/2014/osnovni-ideji (in Ukr).

25. The method of "flow of consciousness" in the work of J. Joyce. Retrieved from http:/ / pidruchniki.com/12631113/literatura (in $\mathrm{Ukr})$.

26. D. Joyce's creativity and the school of "flow of consciousness". Retrieved from http://ukrbukva.net/3425-Tvorchestvo-DzheiymsaDzhoiysa (in Ukr).

\section{Ph.D in Psychology, Associate Professor of the Theoretical and Practical Psychology Department, National University "Lviv Polytechnic" e-mail: yurvin@ukr.net \\ STUDY OF KNOWLEDGE IN EDUCATIONAL WORK WITH STUDENT PSYCHOLOGISTS}

Abstract. Introduction. The preparation of specialists with higher education in modern conditions requires the application of appropriate approaches that allow tracing the progress of science and the process of acquiring knowledge within the various currents, directions and schools, which are necessary for the formation of ideas about its current state. This circumstance also applies to the preparation of future professional psychologists: students should have an adequate understanding of the basic notions of psychological science, which is important to their further successful professional development. The notion of consciousness belongs to such concepts that require the careful elaboration from the first course of study, however, only theoretical knowledge is not enough for its full understanding. This circumstance causes the need for application of a research approach to the educational process, which involves the use of research elements at its various stages; which confirms the actuality of this work.

Purpose. To elucidate the features and the course of application of the research approach to the study of consciousness in the educational work with student psychologists.
Methods. Analysis, synthesis, systematization, specification, generalization.

Results. As a result of the analysis of publications on the subject matter of the study, the specific features of the study of consciousness at different stages in the development of psychological science have been established. Referring to them, an approach has been developed to familiarize students with the study of consciousness, which would allow to combine the existing disparate knowledge of the subject matter on a certain rational basis and present them accessible and in a strictly logical sequence, based on their needs for such knowledge and the existing level of knowledge and professional education requirements. The approbation of the proposed approach to the real teaching and educational process of preparation of future professional psychologists in the university has been implemented.

Originality. A research approach has been developed to familiarize student psychologists with the study of consciousness, which provides for bringing scientific theories as close as possible to the everyday life of each person, in order to make them understandable for students. The approach adequately reproduces the real process of studying consciousness in the preparation training of 
future professional psychologists in a higher education institution; after testing and refinement, it can be recommended for implementation in the teaching and educational process.

Conclusion. The review of scientific publications on the subject matter allows us to state that the existing works contain only a certain set of disparate data that are difficult to unite into a holistic concept suitable for teaching and understanding by students, which creates certain difficulties both in its teaching and mastering by students. The application of the research approach to elucidating of this subject matter in the course of its teaching student psychologists allows to systematize the existing knowledge, expound it in a certain logical sequence and make it more accessible and understandable, as well as, form a positive motivation for its study and overcome a number of difficulties associated with its development. The introduction to the proposed approach makes it possible to raise the interest in studying of this subject matter among students and interest them in the independent study of other aspects, methods and perspectives of consciousness research, which has a positive impact on their involvement in research activities, as well as on the pro- cess of their professional development in the course of a professional learning.

Annotation. The article attempts to highlight the peculiarities and the course of the application of a rational approach to the study of consciousness research in educational work with student psychologists in the process of studying in higher educational institutions. An overview of scientific publications on the subject matter; The subjects and approaches to the study of consciousness are elucidated. The peculiarities of research of consciousness in psychology at different periods of its formation are highlighted. The specificity of involving students in the study of consciousness, at each of the stages of its study, is considered. The conclusions drawn from the work performed and the prospects of further research in this direction are made.

Keywords: research of consciousness, research approach to the educational process, psychological novel, psychological analysis, introspection, flow of consciousness, educational work with student psychologists.

Одержано редакиією 14.08.2018 Прийнято до публікаиіï 19.08.2018

DOI 10.31651/2524-2660-2018-17-19-26

ORCID 0000-0002-0656-2413

DANYLYUK Serhiy,

Doctor in Pedagogy, Professor,

Chair of Higher School Pedagogy and Educational Management Department, Bohdan Khmelnytsky National University at Cherkasy

e-mail: sedan@bigmir.net

УДК 378.091.12 : 364-051 (045)

\section{USE OF COGNITIVE EDUCATIONAL MODELS IN MANAGEMENT OF ESTABLISHMENTS OF EDUCATION}

Abstract. Introduction. The development of education informatization entails a variety of forms of representation of real world. The development of information representation forms leads to the creation of new educational models. One of the new educational models are cognitive educational models.

Cognitive technologies are methods and algorithms for achieving the goals of subjects, based on data about the processes of knowledge, training, communication, processing information by humans and animals, on the presentation of neuroscience, on the theory of self-organization, computer information technologies, mathematical modeling of elements of consciousness, a number of other scientific areas, recently related to the field of fundamental science.

Purpose. The aim of the paper is to specify use of cognitive educational models in management of educational establishments.

Results. Such three areas of cognitive models application, as classical education, multimedia and virtual education and testing are singled out. Two mechanisms that are used by the human thinking and cognitive process (cognitiveness) are characterized. One mechanism makes it possible to work with chains of characters with which semantic meanings are related. In this case, the person works with chains, that is, not with integrated in- formation models. Another mechanism of thinking makes it possible to work with images and representations (models) of these images. It is stated that human thinking and behavior are due to mutual work of both hemispheres of the human brain.

Originality. The major pro and contra arguments of use of cognitive educational models in management of educational establishments are revealed in the paper.

Conclusion. Cognitive educational models are formed on the basis of certain principles and they possess a number of properties that distinguish them from informational educational models. They, on the one hand, contribute to the development of creativity in learning. On the other hand, they create an increased load on teacher and require the development of new methods of cognitive testing.

Keywords: education informatization; cognitive educational models; management of educational establishments; classical education; multimedia and virtual education; testing.

The development of education informatization entails a variety of forms of representation of real world. The development of information representation forms leads to the creation of new educational models. One of the new 